\title{
PEDAGOGIKA OGÓLNA W RAMIE INTERNALISTYCZNEJ
}

Streszczenie: W niniejszym artykule przyjmuję założenie, że forma pedagogiki ogólnej ma charakter autorski. Na jej treści składają się kategorie wynikające z osobistych doświadczeń pedagogów. Tym samym nawołuję do odejścia od ujęć eksternalistycznych i tworzenia koncepcji pedagogiki ogólnej w ramie internalistycznej. W wypowiedzi podaję sugestie, jak tego typu pedagogikę ogólną można by stworzyć.

Słowa kluczowe: pedagogika ogólna, rama internalistyczna, poznanie i kategoryzacja, podmiot pedagogiczny pedagogiki ogólnej.

W myśl łacińskich traktatów, w których stosowano zasadę sensus tituli, również i w tym przypadku zostanie wyjaśnione znaczenia tytułu tej wypowiedzi, w której ideę ramy sprowadzam do metafory akwarium, która ma tutaj odegrać rolę wprowadzającą w tematykę, jak i obrazującą sens tego, o czym będzie mowa.

Często zdarza się w myśleniu naukowym, iż sięga się do metafor ${ }^{1}$, a zastosowana tutaj przenośnia akwarium nie jest czymś nowym ${ }^{2}$. Sformułowany w niniejszej wypowiedzi tytuł, w oczywisty sposób wyjaśnia, że pedagogika ogólna w swojej teoretycznej formie będzie podlegać internalistycznej ramie ${ }^{3}$. Prowadzone przeze mnie rozważania na temat pedagogiki ogólnej stanowią teoretyczny projekt ${ }^{4}$, którego

1 Bardzo dobrym tego przykładem jest książka Bronisława Malinowskiego pt. Argonaucizachodniego Pacyfiku. Relacje o poczynaniach i przygodach krajowców z Nowej Gwinei (1981). Malinowski tematykę mitycznych Argonautów przeplata z życiem mieszkańców wysp Trobrianda.

2 Przykładowo, do metafory akwarium sięgają współautorzy książki Edukacja w czasach cyfrowej zarazy. (Edukacja w czasach cyfrowej zarazy, 2016, s. 85-86).

3 Na temat rozumienia ramy piszę w książce Ramy pedagogiki (Dembiński 2015).

4 Innymi - w moim przekonaniu - interesującymi wariantami, mogącymi dookreślić strukturę pedagogiki ogólnej i które w jakiś sposób dotykają niniejszej propozycji, są: komparatystyka i habitus. W pierwszym przypadku należałoby mieć na uwadze podejście łączące praktykę interpretacyjną $\mathrm{z}$ doświadczeniem pedagogicznym pedagoga $\mathrm{w}$ ujęciu holistycznym i zintegrowanym. Wykraczając poza schemat katalogowania czy inwentaryzacji wiedzy, należałoby kłaść nacisk na sytuowanie wiedzy dotyczącej pedagogiki ogólnej w strukturach poznawczo otwartych. Wskazane byłoby tutaj, jak sugeruje S. Tötösy (Tötösy 2007, s. 45-68), odwołanie się do tak pojmowanej komparatystyki, którą należałoby sprowadzić do wiedzy czy stylu „czytania”, 
abstrakcyjność stanie się bardziej zrozumiała, jeśli rozumienie i wyobraźnię zakotwiczy się w jakieś metaforze. Zainteresowanie metaforami rozpoczęło się w latach 6o. XX wieku (Zeidler 2014). Początkowo sens istnienia metafor odnoszono do życia

integrujących w sobie oddziaływania tekstów kultury z różnymi formami dyskursu. W przypadku pedagogiki ogólnej byłaby to kreacja wiedzy pedagogicznej w kontekście jej historycznych trawestacji z uwzględnieniem antropologii dyskursu transdyscyplinarnego. W tym podejściu - co jest szczególnie dla mnie ważne - uwzględnia się doświadczenie badacza, a więc indywidualną perspektywę pedagoga, którego zaangażowanie i bezpośrednie doświadczenie stają się miarą autentyczności, a także gwarancji spełnienia kryteriów naukowego myślenia. Komparatystyka, tak, jak ją można w tym ujęciu postrzegać, będzie mimo wszystko unikać porównań, a bardziej koncentrować się na autorytecie, na autorskim zakorzenieniu się w świecie, sprowadzonym do sieci przenikających się metod, dyskursów, książek, rozmów, przygód itd. (Kadłubek 2010, s. 179 i n.). Powinno to oznaczać również, że osobiste doświadczenia pedagogów pedagogiki ogólnej w swojej humanistycznej aurze, a więc i spowitej dziedziczoną tradycją pedagogiczną, będą skłaniać się do zespalania treści przeszłości z przyszłością, w jej dopełniającym się poznawczo i metodycznie kształcie. Zapośredniczenie bowiem pedagogiki ogólnej w strukturach umysłowych i egzystencjalnych uczonego nakłada na niego obowiązek epistemologicznego i metodologicznego ujmowania badanego świata przez myśli i działania, których sposoby będą ukazywać praktykę interpretacji (Szczęsna 2010, s. 109). Praktyki te, organizując myślenie i rozumienie zakorzenione w pedagogice, nadają sens temu, co uczony doświadcza w procesie „porównywania”, uogólniania, stosowania syntez, wartościowania, generalizacji czy usensowniania. Interpretując, uczony wchodzi w relacje z tekstem, poprzez który odkrywa siebie uwikłanego egzystencjalnie w egzystencje pedagogiki ogólnej. Uwikłanie to ma podwójny wymiar, ponieważ uczony z jednej strony jest czytelnikiem tekstów, a z drugiej strony kreuje teksty dla czytelników. W ten sposób pedagog pedagogiki ogólnej zapośrednicza w sobie współwypowiadanie się, albowiem teksty czytane mówią, i to, co się w sobie słyszy, tworzy dialog - napięcie, które w swojej potrzebie interpretowania i odkrywania prawdy jest wyrazem dramatu przeniesionego na arenę komunikacji - już ze swoim czytelnikiem, za wiedzę którego bierze się odpowiedzialność w jego wewnętrznym współwypowiadaniu się - czytaniu (Gadamer 2006). W ten sposób komparatystyka sprowadzona do pedagogiki ogólnej zespala pedagoga pedagogiki ogólnej poprzez jego pedagogiczne doświadczenie przystające do praktyk interpretacji z czytelnikiem - studentem, który w wewnętrznym współwypowiadaniu się z uczonym będzie mógł odnaleźć w tekście miejsca otwarte na jego własną refleksję, będącą sposobem na przyswojenie sobie sensu tego, co tekst dla mnie znaczy. Z kolei pedagogika ogólna sprowadzona do habitusu w ujęciu Pierre’a Bourdieu pozwala widzieć w niej „system trwałych i przekazywalnych dyspozycji, ustrukturowanych struktur, predysponowanych do tego, by funkcjonować jako struktury strukturujące" (Bourdieu 2008, s. 72-73). Dyspozycje stanowią o pewnym sposobie bycia treści pedagogiki, które można sprowadzić do kapitału symbolicznego, który w swojej praktyce odniesiony do zmysłu praktycznego decyduje o tym, jak dane treści pedagogiki będą postrzegane, oceniane, interpretowane, uogólniane itd. Dzięki dyspozycjom pedagogika ogólna spełnia oczekiwania społeczne, które w rezultacie pozwalają widzieć w niej formę zinstytucjonalizowaną, narzucającą pedagogice, tj. edukacji i wychowaniu, określone procedury postępowań, które będą przymuszać podmioty do określonych zachowań. W ten sposób można doszukiwać się w pedagogice ogólnej praktycznej formy kapitału kulturowego, który w odniesieniu do wychowania i kształcenia stanowi o swojej historycznej wyższości, podtrzymując swoją dominację pedagogiczną w życiu społecznym, jako wyraz stosowanej wobec agensów przemocy symbolicznej (Bourdieu 2008, s. 170-176). Oznacza to, że struktura pedagogiki ogólnej - jej rozumienie i rozwój - będą podlegać przemocy symbolicznej. 
codziennego (Lakoff, Johnson 1988), a z czasem zaczęto je stosować w nauce, celem dopełnienia innego oglądu odkrywanych zjawisk, czemu wtórowało tworzenie teorii naukowych (Brown 2003). Zastosowana tutaj metafora akwarium w swojej paraleli oznacza pedagogikę ogólną. Ich (akwarium i pedagogiki ogólnej) kształt, i to, co w nich się znajduje, jest zależne od ich właścicieli, od ich wiedzy i posiadanych doświadczeń, których samozwrotne zrozumienie sprowadzam do koncepcji poznania opartej na internalizmie. W myśl tego stanowiska wytwory mentalne oparte są na indywidualnie tworzonych kategoriach. W naszym mentalnym akwarium „pływającymi” kategoriami są ryby. Oprócz ryb zwykle w akwarium mamy glony, muszelki, kamienie itp., i są to imponderabilia, czyli przedmioty, a w szczególności pytania, które mają istotny wpływ na istnienie i przebieg danego zjawiska, a więc tego, co dzieje się w obszarze akwarium (pedagogiki ogólnej). Imponderabilia, jak i ryby znajdują się w określonym środowisku. Tym środowiskiem dla pedagogiki ogólnej jest język, który podporządkowuję retoryce. Oprócz wymienionych elementów w akwarium mamy oświetlenie, filtry, podajniki żywności itp. Elementy te utożsamiam z nowymi technologiami i cyberkulturą, które współcześnie mają duży wpływ na edukację i wychowanie. Akwarium jest zawsze w określonym czasie projektem skończonym, ale jego sensem nie powinno być przymuszanie do oglądania tego, co się w nim wydarza, ale zachęta do stworzenia własnego oglądu rzeczy, co będzie korespondować z oryginałem (zob. rys. 1). Ta wytyczna dotyczy również pedagogiki ogólnej, która nakłada na pedagoga zadanie zachęcania swoich czytelników do własnej kreacji ontologii i hermeneutyki pedagogiki ogólnej.

Rysunek 1. Pedagogika ogólna jako akwarium

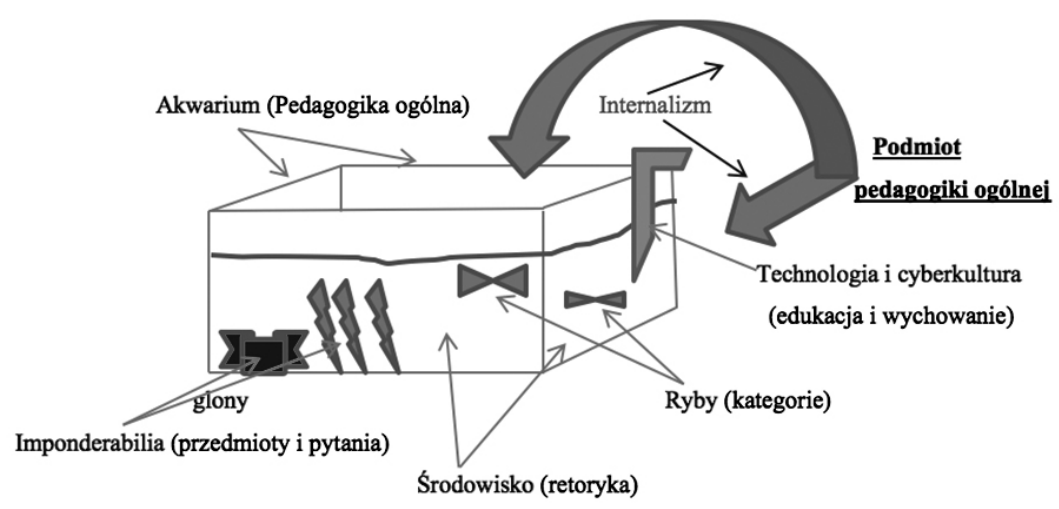

Źródło: opracowanie własne.

W niniejszej wypowiedzi przyjmuję następujące założenia dotyczące pedagogiki ogólnej. Pedagogika ogólna ma charakter autorski. Jej koncepcje, a tym samym definicje, zbudowane są w oparciu o kategorie, które wyłaniają się na bazie osobistych doświadczeń i to na sposób internalistyczny. Są one zatem uwikłane w sposób funkcjonowania ludzkiego umysłu, poznawczo i rozwojowo wynikają 
z osobistych doświadczeń ich twórców. Pojawiające się w konsekwencji projekty pojmowania pedagogiki ogólnej, niezależnie od tego, czy będą składać się na teorie, czy też tylko na jej definicje, to będą one w zasadzie zdominowane przez kategorie, których scalającymi nośnikami w językowej argumentacji i perswazji będą - w tej tutaj propozycji - tropy i figury retoryczne. Wydaje się, że idealny model pedagogiki ogólnej nacechowany byłby osobistymi wyznaniami jego autora czy autorów, które dotyczyłyby źródeł, doświadczeń i przemyśleń na jego temat. Jest to dlatego ważne, ponieważ w podejściu internalistycznym kategorie są konstruowane na bazie nieustannie ucieleśnionego doświadczenia, posiadanej w danym czasie wiedzy i wyobraźni (Rosch 1977). Oznaczać to powinno w konsekwencji, iż powoływane do istnienia i funkcjonowania w środowisku retoryki struktury kategorii powinny być ontologicznie otwarte i to w tym sensie, że będą ujawniać gotowość do wewnętrznych przekształceń, wchodzenia w relacje z innymi kategoriami, a nawet i z poza systemu. Same zaś środowisko pedagogiki ogólnej powinno być wypełnione mocą sprawczą retoryki, a więc formą ludzkiego rozumowania, będącą sztuką perswazji i nakłaniania (Perelman 2004).

$\mathrm{Na}$ realizację powyższego konceptu powinny składać się pytania, które będą dotyczyć podstaw wyłaniania się takiej struktury poznawczej, jaką jest pedagogika ogólna. Wydaje się, że zapośredniczony w niej sens istnienia, jej narzędziowy charakter, powinien w swojej poznawczej, uogólnionej, generalizującej, interpretacyjnej itd. formule być zależny od retorycznej postawy uczonego, konceptualizującego swoje przemyślenia na sposób, w który będzie zapraszać swoich czytelników do osobistego, osobowego zaangażowania, warunkowanego zaciekawieniem. Jest to dlatego ważne, ponieważ pedagogika ogólna zdaje się być jednym z najbardziej abstrakcyjnych przedmiotów na studiach pedagogicznych - i dlatego poprzez dostosowanie uczonego do wymagań podejścia internalistycznego staje się możliwe przekroczenie jej bezosobowej struktury i wkroczenie w płaszczyznę żywej interakcji, która będąc nacechowana zasadami obowiązującymi w retoryce, bliższa staje się humanistycznej wykładni poznania, niż społecznym poszukiwaniom reguł jej funkcjonowania, przez co sens zjawisk edukacyjnych w swoim pedagogicznym uogólnianiu zbliża się bardziej do aktu wychowania, samowychowania niż procesu bycia edukowanym.

W moim przekonaniu, jeżeli chodzi o budowanie z czytelnikiem relacji intrai transpersonalnych, znakomitym tego przykładem jest ostatnia książka Zbyszko Melosika Piłka nożna. Tożsamość, kultura i władza (Melosik 2016). W narrację tej wypowiedzi wpisują się nie tylko cytaty szkicujące obrys poruszanych tematów, ale istotne stają się osobiste wyznania autora, które stanowią podbudowę dla wewnętrznych rozważań czytelnika, wymuszanych procesem zagłębiania się w proces czytania czy też wnikania w teksturę wypowiedzi.

Przystępując do próby wykreowania nieco innego oblicza pedagogiki ogólnej, które w tym przypadku powinno się opierać się na formalnym przeformułowaniu jej podstaw, nie można bać się podważania jej dotychczasowego dorobku. Kluczowe 
i wręcz obowiązkowe powinno być krytyczne odniesienie się do funkcjonujących w polskiej rzeczywistości koncepcji pedagogiki ogólnej, głównie wskazujących na eksternalistyczne podstawy i wpisujący się w nie paradygmat obiektywistyczny, którego metafizyka i epistemologia buduje swoje odniesienia do rzeczywistości na modelach przystających do teorii zbiorów. Krytyka ta powinna nawiązywać do współczesnych ustaleń poznawczych, gdzie przykładowo powiązany z paradygmatem obiektywistycznym realizm metafizyczny świadczy o epistemologicznej niespójności poglądów dotyczących znaczenia, odniesienia, wiedzy i rozumienia (Putnam 1981). Należy również krytycznie odnieść się do tych idei w socjologii, które opierają swoje podstawy na idei reprezentacji. Jest to ważny fundament współczesnej socjologii, do słabości którego przyznają się jej teoretycy, widząc w tym aspekcie kryzys tej dyscypliny (Beart, Carreira da Silva 2013). Kryzys ten przekłada się na nauki społeczne Nie można też bezkrytycznie odnieść się do filozofii. Przykładowo, teoria prototypów i kategorii poziomu podstawowego, opracowana przez Eleonor Rosch, w sposób doświadczalny podważa przeszło dwutysięczną tradycję filozoficzną na temat natury rozumu. Tradycję tę, jak pisze George Lakoff, określa się mianem obiektywizmu, ponieważ „współczesne próby jego zastosowania zakładają, że rozumna myśl opiera się na manipulowaniu abstrakcyjnymi symbolami i że symbole te nabierają znaczenia na drodze powiązań ze światem konstruowanym obiektywnie, tj. niezależnie od jakiegokolwiek pojmującego go organizmu. Zbiór symboli powiązanych z obiektywnie konstruowanym światem postrzegany jest jako reprezentacja rzeczywistości. Według ujęcia obiektywistycznego, całe rozumne myślenie polega na manipulowaniu abstrakcyjnymi symbolami, które otrzymują znaczenie wyłącznie na drodze konwencjonalnych powiązań z rzeczami w świecie zewnętrznym" (Lakoff 2011, s. X) - powiązań z konkretnymi rzeczami albo z konkretnymi kategoriami. Szukając argumentów dla krytyki obiektywizmu, warto również sięgnąć do przedstawicieli filozofii analitycznej (Szubka, red. 1995; Szubka 2009; Leclercq 2008), semantyki/gramatyki kognitywnej (Kubiński 2014; Aloni i in. 2007), fenomenologii ciała (Merleau-Ponty 2001; Błajet, red. 2010), przemyśleń Willarda van Ormana Quine’a (1986), Paula Feyerabend'a (1996), Hilary Putnam (2013).

Propozycję ukonstytuowania pedagogiki ogólnej na założeniach internalistycznych można by przykładowo rozpocząć od krytycznego podejścia do tradycyjnego definiowania kategorii, w których się mówi, że jest to zespół cech wspólnych i to, co wspólne, stanowi podstawę do ich zdefiniowania. Przystępując do krytyki, warto przyjąć za Nicolai Hartmannem (2000, s. 13) jego podział kategorii, które co ważne - utożsamił z zasadami. Filozof ten podzielił kategorie na poznawcze $\mathrm{i}$ bytowe, wyróżniając $\mathrm{w}$ tych drugich kategorie realne oraz idealne. Podział ten może okazać się znaczący w sytuacji, w której przyjmuje się ucieleśniony charakter kategorii, z którego wynika, że kategorie mają strukturę, a struktura nabiera znaczenia poprzez ucieleśnienie, będące wynikiem doświadczania świata przez 
kreatora (pedagoga pedagogiki ogólnej) kategorii i schematów wyobrażeniowych (Johanson 1987).

Jednym z pierwszych, który wpłynął na zmianę postrzegania kategorii, był Ludwik Wittgenstein. Poczynając od jego rozważań na temat kategorii gra, w książce Dociekania filozoficzne (Wittgenstein 2004) kategoria przestaje być ujmowana jako aksjomat, a zostaje sprowadzona do oglądu teoretycznego. Jednak rzeczywiste zmiany w pojmowaniu kategorii dokonały się dzięki badaniom Eleonor Rosch (1978). Wykazała ona, że kategorie zawierają elementy, które mogą świadczyć o tym, że niektóre z kategorii mogą być lepszymi przykładami czegoś od innych i nazwała je prototypami. Co więcej, ich sens i znaczenie są zależne od ludzkiej neurofizjologii, motoryki, zdolności postrzegania, tworzonych obrazów mentalnych, uczenia się, zdolności zapamiętywania, organizowania tego, co się przyswaja oraz od efektywności komunikowania się z innymi. Zestawiając za G Lakoffem (2011, s. 11-55) informacje dotyczące kategorii, należy stwierdzić, że charakteryzują je: podobieństwo rodzinne, centralność, polisemia, generatywność, stopień przynależności, stopień centralności, ucieleśnienie pojęciowe, ucieleśnienie funkcjonalne, kategoryzacja na poziomie podstawowym, nadrzędny status poziomu podstawowego i rozumowanie metonimiczne. Wszystkie wytyczne dotyczące kategorii można sprowadzić do zasad, które przeniesione w obszar pedagogiki ogólnej nadają jej poznawczej strukturze inny sens (zob. tabela 1).

Tabela 1. Zasady kształtujące elementy kategorii

\begin{tabular}{|c|c|}
\hline $\begin{array}{c}\text { Kategoria: np. pedagogika ogólna - } \\
\text { jej elementy: }\end{array}$ & Zasady \\
\hline 1. Nie muszą mieć cech wspólnych & 1. Podobieństwo rodzinne \\
\hline $\begin{array}{l}\text { 2. Charakteryzują kategorię w sposób } \\
\text { „lepszy” lub „gorszy” }\end{array}$ & 2. Centralność \\
\hline $\begin{array}{l}\text { 3. Poprzez znaczenia wyrazów tworzą } \\
\text { kategorie }\end{array}$ & 3. Polisemia \\
\hline $\begin{array}{l}\text { 4. Są generatorami definicji jako cen- } \\
\text { tralne prototypy kategorii }\end{array}$ & 4. Generatywność \\
\hline $\begin{array}{l}\text { 5. Decydują o stopniowalności i braku } \\
\text { wyraźnych granic }\end{array}$ & 5. Stopień przynależności \\
\hline $\begin{array}{l}\text { 6. Przypisane do niższego rzędu mogą } \\
\text { być centralne }\end{array}$ & 6. Stopień centralności \\
\hline $\begin{array}{l}\text { 7. Są zależne od człowieka (biologia, } \\
\text { środowisko) }\end{array}$ & 7. Ucieleśnienie pojęciowe \\
\hline
\end{tabular}




\begin{tabular}{|c|c|}
\hline $\begin{array}{c}\text { Kategoria: np. pedagogika ogólna - } \\
\text { jej elementy: }\end{array}$ & Zasady \\
\hline 8. Funkcjonują w sposób nieświadomy & 8. Ucieleśnienie funkcjonalne \\
\hline $\begin{array}{l}\text { 9. W swoim poznaniu znajdują się } \\
\text { „W” pomiędzy }\end{array}$ & $\begin{array}{l}\text { 9. Kategoryzacja na poziomie tworzo- } \\
\text { nej hierarchii podstawowym }\end{array}$ \\
\hline $\begin{array}{l}\text { 10. W poziomie podstawowym są fun- } \\
\text { kcjonalnie i epistemologicznie pier- } \\
\text { wotne od postrzegania całościowego }\end{array}$ & $\begin{array}{l}\text { 10. Pierwszorzędny status poziomu } \\
\text { podstawowego }\end{array}$ \\
\hline $\begin{array}{l}\text { 11. Mogą zastępować w procesach my- } \\
\text { ślowych całość }\end{array}$ & 11. Rozumowanie metonimiczne \\
\hline
\end{tabular}

Źródło: opracowanie własne.

Przykładowo - upraszczając - jeżeli zwrócimy się do jednej z najbardziej popularnych definicji pedagogiki ogólnej, którą znajdziemy m.in. w Leksykonie PWN. Pedagogika (Milerski, Śliwerski, red. 200o), uzyskamy strukturę, na którą będą składać się przedmioty i kategorie (zob. rys. 2). Przedmiotami określam wszelkie formy działań wpisujące się w tę definicję, natomiast kategoriami ich efekty, do których w tym przypadku należą kompleksy tematyczne, uwarunkowania filozoficzne, metodologiczne itd. ${ }^{5}$.

Przyjęte zatem wstępne rozpoznanie na temat kategorii wpisujących się w pedagogikę ogólną ma stanowić projekt kreacji jej podstawy, którą należałoby tutaj w dalszej kolejności traktować jako narzędzie procesu myślowego zachodzącego w umysłach uczonych, którzy tę definicję kreowali, poczynając od Stanisława Palka, poprzez Teresę Hejnicką-Bezwińska itd. Powyższa propozycja nakazuje zatem widzieć w pedagogice ogólnej, po pierwsze, kategorię poznawczą kształtowaną przez jej kreatorów, a po drugie kategorię realną i kategorię ideową w ujęciu N. Hartmann - edukacyjnie

5 Definicja ta ma następującą formułę: „Pedagogika ogólna - dyscyplina pedagogiki zajmująca się jej podstawami teoretycznymi. Pedagogika ogólna stawia pytania o status pedagogiki i jej uwarunkowania filozoficzne i metodologiczne oraz powiązania z praktyką edukacyjną; bada swoistość i kontekst historyczny zjawisk, procesów, zdarzeń i faktów wychowawczych, zacieśniając $\mathrm{w}$ ten sposób swoje związki z historią wychowania poprzez wydobywanie na jaw podstawowych kategorii pedagogicznych; współczesna pedagogika ogólna zmierza więc ku wiedzy fundamentalnej, a badając stosowne metody poznawcze rzeczywistości wychowawczej, zbliża się do stanu metapedagogiki, czyli wiedzy umożliwiającej opis i krytyczną analizę samych nauk pedagogicznych oraz ideologii, doktryn i systemów wychowawczych. W skład zagadnień pedagogiki ogólnej wchodzą następujące kompleksy tematyczne: 1) współczesne kierunki i ideologie pedagogiczne; 2) filozofia wychowania;3) aksjologia wychowania; 4) metodologiczne przesłanki pedagogiki; 5) ontyczne podstawy wychowania i jego funkcje społeczne; 6) język pedagogiki i ustalenia terminologiczne; 7) tożsamość pedagogiki; 8) metateoria pedagogiki; 9) relacje pomiędzy teorią a praktyką edukacyjną; 10) miejsce edukacji w kontekście przemian cywilizacyjnych" (Milerski, Śliwerski, red. 200o, s. 54). 
Rysunek 2. Struktura definicja pedagogiki ogólnej według B. Milerskiego i B. Śliwerskiego

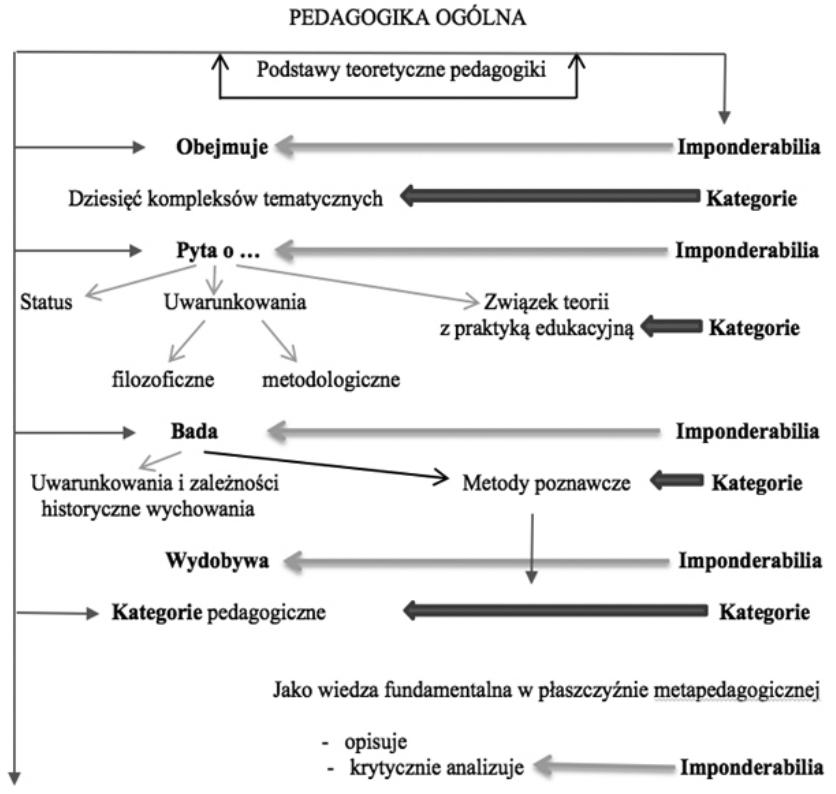

Źródło: opracowanie własne.

i wychowawczo kształtującą ich odbiorców (czytelników). Oznacza to, że struktura pedagogiki ogólnej, sprowadzona do narzędzia poznania, jest zależna od procesów myślowych zachodzących w umysłach osób kształtujących jej rozumienie, które ma charakter subiektywny, internalistyczny, toteż rzeczywiste jego zobiektywizowanie - w moim przekonaniu - dokonuje się za sprawą retoryki i jej tropów oraz figur sprowadzonych ostatecznie do autorskiego modelu (teorii) poznania.

Nie ma tutaj miejsca na głębsze rozważania, ale poszukując podstaw dla urzeczowienia przedmiotów i kategorii pedagogiki ogólnej w środowisku retorycznym, które ma stanowić kanwę dla działalności poznawczo-pedagogicznej jej kreatorów, należy zwrócić się do argumentów służących poznawczej funkcji retoryki. Przede wszystkim w odniesieniu do filozofii warto zmierzyć się z jej głównymi kierunkami (Cherwitz 2011). W przypadku realizmu należy położyć nacisk na to, iż retoryka umożliwia zrozumienie i poznanie pozajęzykowej rzeczywistości. Jeśli sprowadzi się ją do praktyki komunikacji, to będzie służyć weryfikacji wiedzy i pogłębiać poznanie. W przypadku relatywizmu, który to, co rzeczywiste, sprowadza do konstruktów społecznych lub symbolicznych, i który to jednak ideologizuje, jak również marginalizuje tropy retoryki, należy wskazać na pełnione przez nią funkcje przekształcające. W odniesieniu do idealizmu warto położyć nacisk na jej związek z językiem, poprzez który kształtuje formy życia umysłowego. Z kolei warto pamiętać, że egzystencjalizm sięga po retorykę po to, aby odnaleźć w niej nie tylko formę służąca komunikacji, lecz przede wszystkim narzędzie, którego indywidualizm prowadzi do rozwoju dyskursów. Z pragmatycznego punktu widzenia, jakże istotnego dla pedagogiki, retoryka jest utożsamiana z phronesis, z czymś, co Arystoteles powiązał z roztropnością 
Rysunek 3. Struktura kreacji kategorii pedagogiki ogólnej przez podmiot pedagogiczny

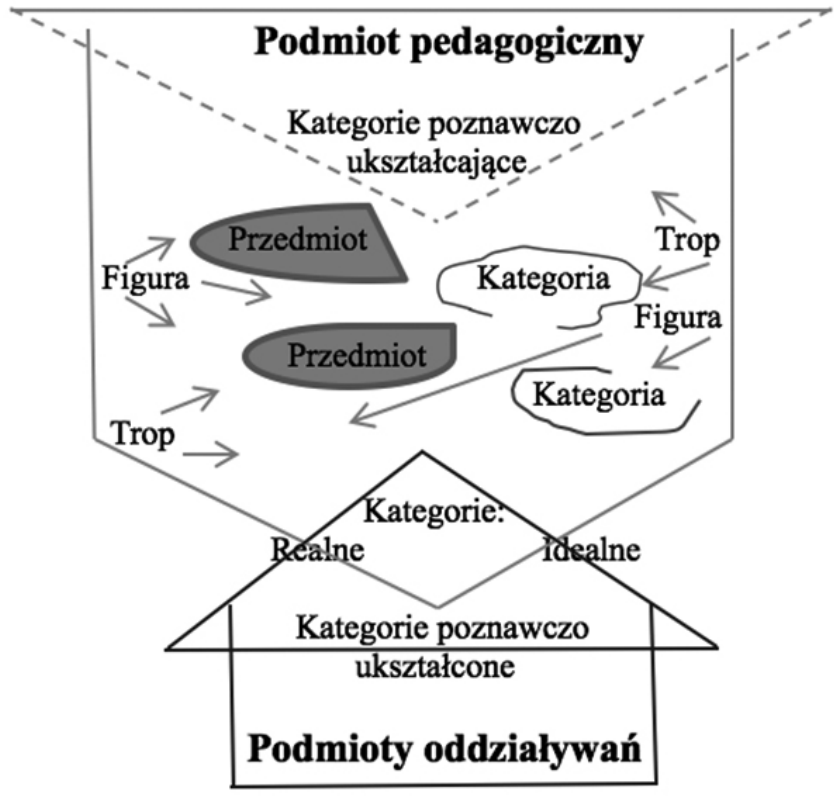

Źródło: opracowanie własne.

i przeciwstawiał wiedzy teoretycznej (episteme) oraz technicznej (techné). Niewątpliwie warto sięgnąć do elementarza retoryki, tj. Progymnasmaty (Podbielski, oprac. 2013).

W książce Pedagogiczne tworzenie istoty ludzkiej (Dębiński 2013) propagowałem ideę homo pedagogigusa, opowiadając się za platońskim ideałem wychowania, w którym położyłem nacisk na kształtowanie podmiotowości, i którą nota bene sytuowałem $\mathrm{w}$ przestrzeni wirtualnej, poza ciałem i duchem. W tym podejściu sens bycia człowiekiem należy usytuować w idei homo rhetoricus (Rusinek 2003, s. 211-258), w której to, idąc przykładem nie Platona i wychowania opartego na dialektyce, a Isokratesa, dla którego w działaniu kształtującym człowieka chodziło o „wysubtelnienie myśli”, należałoby zwrócić większą uwagę na towarzyszące człowiekowi w poznaniu emocje, których szczerość wskazuje na to, co autentyczne, co w edukacji prawdziwe. R. Lanham w tym kontekście pisze: „Edukację ucznia rozpocząć wcześnie. Nauczyć go skupić się na słowie, pisać, mówić i zapamiętywać słowa. [...] Niech dla dziecka słowa będą najpierw przedmiotami i dźwiękami, zanim będą mogły uzyskać pełne znaczenie. Żeby można było najpierw spojrzeć na nie, zanim będzie można spojrzeć przez nie" (cyt. za: Rusinek 2003, s. 2016).

Urzeczywistniane zatem autorskie spojrzenie na pedagogikę ogólną pozwala ostatecznie, poprzez własne doświadczenia i schematy wyobraźni wskazać te kategorie poznawcze, których zasady ustanawiają to, co dla pedagogiki ma się okazać istotne, w rzeczy samej jest aktem wykonania o performatywnej strukturze. Warto o tym pamiętać, ponieważ przykładowo dla Ervinga Goffmana (1981) w wykonaniu zawsze przejawia się forma pedagogiki i to ona decyduje, co jest grane i jak 
odgrywane; natomiast dla Victora Turnera wykonanie oznacza procesualne dochodzenie do spełnienia, które wskazuje na organizację, strukturę, a ta w swoim dopełnianiu jest najbardziej twórcza i treściowo zintegrowana. Tak i pedagogika ogólna w osnowie retorycznych wykonań nie jest formą przypadkową i warto tutaj sięgnąć do opracowań, w których wykonanie jest nadzorowane przez takie cechy, jak podejście intencjonalne, zależność od kontekstu, epizodyczność i improwizacja (Pacanowsky, O’Donnell-Trujillo 1996, s. 293-297).

Pedagogika ogólna w swoim toposie okazuje się zatem miejscem dla formy, w której staje się możliwe przekształcanie ludzkiej osobowości. Zawarte w niej przedmioty wskazują na kierunki jej rozwoju. Przedmioty te, będąc konstruktami opartymi na pytaniach, wyznaczają czytelnikom przestrzeń, w której mogą dyskutować z tropami i figurami retorycznymi wprowadzanymi przez kreatorów pedagogiki ogólnej. Tropy bowiem zastępując jedno słowo innym, budują zgoła inną rzeczywistość, inny świat, inne rozumienie siebie. Figury zaś należy traktować jako nośniki kreacji, jako fałdy - w rozumieniu Gillesa Deleuzea (2014) - w wyniku których dokonuje się zakrzywienie płaszczyzny oddziaływań, prowadzące do ujawniania się podmiotów: pedagoga pedagogiki ogólnej i czytelnika.

\section{Bibliografia}

Aloni M., Batler A., Dekker P. (2007). Questions in dynamic semanics. Amsterdam: Elsevier.

Beart P., Carreira da Silva F. (2013). Teorie społeczne w XX wieku i dzisiaj. Kraków: Nomos.

Błajet P. (red.). (2010). Ciało-edukacja-umysł. Zbiór rozpraw. Bydgoszcz: Wydawnictwo Uczelniane Wyższej Szkoły Gospodarki.

Bourdieu P. (2008). Zmyst praktyczny. Kraków: Wydawnictwo UJ.

Brown T. L. (2003). Making Truth. Metaphor in Science. Chicago: Cambridge University Press.

Cherwitz R. (red.). (2011). Rhetoric and Philosophy. New York and London: Routledge.

Deleuze G. (2014). Fałda. Leibniz a barok. Warszawa: PWN.

Dembiński M. (2013). Pedagogiczne tworzenie istoty ludzkiej. Poznań: Wydawnictwo Naukowe UAM.

Dembiński M. (2015). Ramy pedagogiki. Poznań: Wydawnictwo Naukowe UAM.

E. Goffman. (1981). Człowiek $w$ teatrze życia codziennego. Warszawa: PIW.

Feyerabend P.K. (1996). Przeciw metodzie. Wrocław: Siedmioróg.

Gadamer H-G. (2006). Tekst i interpretacja, W: Burzyńska A., Markowski M.P. (red.). Teoria literatury XX wieku. Antologia. Kraków: Znak.

Hartmann N. (200o). Jak w ogóle możliwa jest krytyczna ontologia? Przyczynek do ugruntowania ogólnej nauki o kategoriach. W: tenże. Principia. Pisma koncepcyjne z filozofii i socjologii teoretycznej. T. 27-28. 
Johanson M. (1987). The body in the Mind. The bodily of Meaning, Imagination, and Reason. Chicago: University of Chicago Press.

Kadłubek Z. (2010). Święta Medea. W stronę komparatystyki pozasłownej. Katowice: Wydawnictwo Uniwersytetu Śląskiego.

Kasprzyk P., Kłakówna Z. A., Kołodziej P., Regiewicz A., Waligóra J. (red.). (2016). Edukacja w czasach cyfrowej zarazy. Toruń: Wydawnictwo Adam Marszałek.

Kubiński W. (2014). Obrazowanie a komunikacja. Gramatyka kognitywna wobec analizy dyskursu. Gdańsk: Fundacja Terytoria Książki.

Lakoff G., Johnson M. (1988). Metafory w naszym życiu. Warszawa: PIW.

Lakoff G. (2011). Kobiety, ogień i rzeczy niebezpieczne. Co kategorie mówia nam o umyśle. Kraków: Universitas.

Leclercq B. (2008). Introduction á la philosophie analytique. La logique comme méthody. Bruxelies: De Boeck.

Malinowski B. (1981). Argonauci zachodniego Pacyfiku. Relacje o poczynaniach i przygodach krajowców z Nowej Gwinei. Warszawa: PWN.

Melosik Z. (2016). Piłka nożna. Tożsamość, kultura, władza. Poznań: Wydawnictwo Naukowe UAM.

Merleau-Ponty M. (2001). Fenomenologia percepcji. Warszawa: Fundacja Aletheia.

Milerski B. Śliwerski B. (red.). (200o). Pedagogika. Leksykon. Warszawa: PWN.

Pacanowsky M.E., O’Donnell-Trujillo N. (1996). Komunikacja organizacyjna jako forma „wykonania” kulturowego. W: Kapciak A., Korporowicz L., Tyszko A. (red.). Komunikacja międzykulturowa. Zdarzenia i spotkania. Antologia tekstu. Warszawa: Instytut.

Perelman Ch. (2004). Imperium retoryki. Retoryka i argumentacja. Warszawa: PWN.

Podbielski H. (oprac.). (2013). Progymnasmata. Lublin: Towarzystwo Naukowe Katolickiego Uniwersytetu Lubelskiego Jana Pawła II.

Putnam H. (1981). Reason, Truth, and History. Cambridge: Cambridge University Press.

Putnam H. (2013). Wiele twarzy realizmu i inne eseje. Warszawa: PWN.

Rosch E. (1977). Human Categorization, W: Warren N. (red.). Studies in CrossCultural Psychology. London: Academic.

Rosch E. (1978). Cognition and Categorization. Hillsdale: Lawrence Erlbaum Associates.

Szczęsna E. (2010). Ontologia i epistemologia porównania. W: Szczęsna E., Kasperski E. (red.). Komparatystyka dzisiaj. Problemy teoretyczne. T. 1. Kraków: Universitas.

Szubka T. (red.). (1995). Metafizyka w filozofii analitycznej. Lublin: KUL.

Szubka T. (2009). Filozofia analityczna. Koncepcje, metody, ograniczenia. Warszawa: WUW.

Tötösy S. (2007). The New Humanities. The Intercultural, the Comparative, and the Interdisciplinary. „The Global South”, vol. 1, nr 1-2.

Van Orman Quine W. (1986). Granice wiedzy i inne eseje filozoficzne. Warszawa: PIW. 
Wittgenstein L. (2004). Dociekania filozoficzne. Warszawa: PWN.

Zeidler P. (2014). O roli ugruntowanych empirycznie metafor w naukowych programach badawczych. W: Filozofia i Nauka. Studia filozoficzne i interdyscyplinarne. T. 2.

\title{
PHILOSOPHY OF EDUCATION IN THE INTERNALISTIC FRAME
}

\begin{abstract}
In this article, I make an assumption that general pedagogy has an authorial character. Its content is composed of categories which result from personal experiences of pedagogues. Thus, I call for a departure from externalistic approaches and creation of the concept of philosophy of education in the internalistic frame. In the comments I give suggestions how this type of philosophy of education could be created.
\end{abstract}

Key words: philosophy of education, internalistic frame, cognition and categorization, pedagogical subject of philosophy of education.

Mariusz Dembiński - dr hab., adiunkt w Zakładzie Pedagogiki Wydziału PedagogicznoArtystycznego w Kaliszu na Uniwersytecie im. Adama Mickiewicza w Poznaniu. Adres do korespondencji: ul. Czysta 10 m 1, 61-367 Poznań. Adres e-mailowy: mdmd@amu.edu.pl. 